\title{
Root colonization by arbuscular mycorrhizal fungi (AMF) in various age classes of revegetation post-coal mine
}

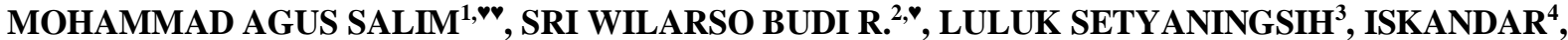 \\ IMAM WAHYUDI ${ }^{5}$, HIFZIL KIRMI ${ }^{6}$ \\ ${ }^{1}$ Program of Silviculture Tropica, Department of Silviculture, Faculty of Forest, Institut Pertanian Bogor. Jl. Ulin, Kampus IPB Dramaga, Bogor 16680, \\ West Java, Indonesia. Tel.: +62-251-8626806, Fax.: +62-251-8626886, ``email: agussalim.ipb@gmail.com \\ ${ }^{2}$ Department of Silviculture, Faculty of Forest, Institut Pertanian Bogor. Jl. Ulin, Kampus IPB Dramaga, Bogor 16680 West Java, Indonesia \\ Tel.: +62-251-8626806, Fax.: +62-251-8626886, •email: wilarso62@ yahoo.com \\ ${ }^{3}$ Faculty of Forest, Universitas Nusa Bangsa. Jl. KH. Sholeh Iskandar Km 4, Bogor 16166, West Java, Indonesia \\ ${ }^{4}$ Center Study of Mine Reclamation, Institut Pertanian Bogor. Jl. Lingkar Akademik, Kampus IPB Dramaga, Bogor 16680 West Java, Indonesia \\ ${ }^{5}$ Departemen of Forest Product, Faculty of Forest, Institut Pertanian Bogor. Jl. Ulin, Kampus IPB Dramaga, Bogor 16680 West Java, Indonesia \\ ${ }^{6} \mathrm{PT}$. Berau Coal. Berau 77311, East Kalimantan, Indonesia
}

Manuscript received: 31 August 2020. Revision accepted: 5 October 2020

\begin{abstract}
Salim MA, Budi RSW, Setyaningsih L, Iskandar, Wahyudi I, Kirmi H. 2020. Root colonization by arbuscular mycorrhizal fungi $(A M F)$ in various age classes of revegetation post-coal mine. Biodiversitas 21: 5013-5022. This study aims to evaluate the status of colonization of the roots of the host plant in various age classes of revegetation of post-coal mining land associated with AMF spores populations and soil fertility. The study was conducted in the post-mining revegetation land at PT. Berau Coal, East Kalimantan. Isolation of the spores was carried out using the wet-sieving and centrifugation method, while the colonization of the roots was done by the root coloring technique. Result showed that revegetation activities were able to increase the content of some nutrients in the soil. The AMF population showed tendency an increase along with the increasing revegetation age classes. Eight-year revegetation age classes had the highest average number of spores. Plant species and understorey have shown the existence of AMF colonization with different values for each species. AMF root colonization had a negative relationship with the number of spores in the soil. The $\mathrm{C}$-organic, $\mathrm{N}$-total, CEC Ca, Mg and Fe contents had a positive correlation with AMF root colonization, while available $\mathrm{P}$, total $\mathrm{P}, \mathrm{K}$, and $\mathrm{Al}$ had a negative correlation with AMF root colonization. Mg was significantly correlated $(r=0.861)$ to AMF root colonization.
\end{abstract}

Keywords: AMF, revegetation, root colonization, spores, soil nutrient

\section{INTRODUCTION}

Post-mining land reclamation activities need to be carried out to restore land productivity (Mushia et al. 2016) as same as the condition before mining activities. Revegetation is one of the activities undertaken after postmining land reclamation activities. Revegetation is an effective way to reduce soil erosion and protect the soil during the reclamation process (Sheoran et al. 2010). The success of revegetation is greatly supported by the presence of soil microorganisms, especially Arbuscular Mycorrhizal Fungi (AMF). AMF plays an important role in ecosystem sustainability, soil ecological balance, plant development, and biodiversity maintenance (Ezeokoli et al. 2019; Krüger 2017; Bi et al. 2018).

AMF is one of microorganism that has a very important role in almost every ecosystem (Chairul et al. 2019; Pinos et al. 2019), especially in post-mining lands (Krüger et al. 2017). AMF can make the relationship between the abiotic and biotic components of the ecosystem (Kumar et al. 2010). AMF is very common in disturbed land and shows a positive role both in the growth and development of plant communities. AMF is the key to the success of the restoration process of soil ecological functions (Ezeokoli et al. 2019) and rehabilitation processes (Gosling et al. 2016) especially on degraded lands including mined land. AMF is one of the potential biotechnologies to enhance and support the success of revegetation and revegetation on degraded lands (Asmelash et al. 2016).

Generally, post-mining land has low fertility, which is characterized by poor physical, chemical, and biological properties of the soil (Mushia et al. 2016), thus causing suboptimal plant growth. The presence of AMF on coalmining land can help in plant growth and the succession process (Sousa et al. 2014). AMF helps plant growth in absorbing water and nutrients (Goltapeh et al. 2013; Kumar et al. 2010; Polcyn et al. 2019; Wu et al. 2015), increasing plants resistance against drought stress and salinity (Bhuvaneswari et al. 2014; Doubková et al. 2011; Latef and Chaoxing 2011; Porcel et al. 2015; Shi-chu et al. 2019), plant protection of root pathogens (Banuelos et al. 2014; Oyewole et al. 2017; Veresoglou and Rillig 2012; Yang et al. 2014), increasing plants in tolerating heavy metals (phytoremediation) (Cabral et al. 2015; Husna et al. 2016; Rajtor and Piotrowska-Seget 2016; Tian et al. 2013). Also, AMF can improve and stabilize soil structure through glomalin production (Matthiasc et al. 2010; Rillig et al. 2015), increase plant growth and plant fitness (Barea et al. 2011; Husna et al. 2019, 2020; Janoušková et al. 2017; Musyoka et al. 2020) and increase crop productivity (Sing 
and Jamaluddin 2011). The symbiosis of AMF and plants can influence interactions between plants, plant structure, increase crop production, ecosystem recovery, and conservation of the ecosystem (Davison 2015). More than $80 \%$ of plant growth surveys in mining areas have been colonized by the AMF (Wang 2017). The existing plants in the post-coal mining land are associated with AMF quite well (Kumar et al. 2003), thereby increasing plant survival. Research on AMF has been conducted in various postmining lands in Indonesia, such as in post-mining areas of gold (gold tailings) (Suharno et al. 2016, 2017; Tuheteru et al. 2019), in post-coal mining areas (Husin et al. 2017; Salim et al. 2019; Ulfa et al. 2011), and post-nickel mining areas (Setiadi and Setiawan 2011; Prayudyaningsih et al. 2018). However, there are still few reports regarding the status of AMF for various revegetation age groups on postcoal mining land. Therefore, AMF has a very important and significant role in ecological restoration (Asmelash et al. 2016), especially on ex-mining land (Wang 2017). The aim of this study is to evaluate the status of colonization of the roots of the host plant in various age classes of revegetation of post-coal mining land associated with AMF spores populations and soil fertility.

\section{MATERIALS AND METHODS}

\section{Study area}

The study was conducted at the post-coal mining area of the Binunga site, PT. Berau Coal, East Kalimantan, Indonesia. The samples were taken in November 2019. Soil and root samples were taken from several revegetation age classes i.e. 2, 4, 6, 8, 10, and 12 years (Table 1). Soil sampling refers to the method of Sahner et al. (2015) using a $50 \mathrm{~m} \times 50 \mathrm{~m}$ plot and there were three $5 \mathrm{~m} \times 5 \mathrm{~m}$ subplots. Soil samples were taken from 0-20 cm deep from each subplot, while root samples were taken from 4 trees in each subplot.

\section{Soil analysis}

The parameters were analyzed by different methods (Table 2) based on Eviati and Sulaeman (2009). The chemical properties of the soil were analyzed by 13 parameters, while the physical properties were measured only by the soil texture.

Table 1. Sampling location several revegetation age classes

\begin{tabular}{|c|c|c|c|c|}
\hline \multirow{2}{*}{$\begin{array}{c}\text { Revegetation } \\
\text { age (years) }\end{array}$} & \multirow{2}{*}{$\begin{array}{c}\text { Revege- } \\
\text { tation } \\
\text { years }\end{array}$} & \multirow{2}{*}{$\begin{array}{c}\text { Area } \\
\text { (ha) }\end{array}$} & \multicolumn{2}{|c|}{ Coordinate } \\
\hline & & & North & East \\
\hline 2 & 2017 & 5.00 & $01^{\circ} 59^{\prime} 20.2^{\prime \prime}$ & $117^{\circ} 24^{\prime} 8.9^{\prime \prime}$ \\
\hline 4 & 2015 & 14.80 & $01^{\circ} 59^{\prime} 10.6^{\prime \prime}$ & $117^{\circ} 23 ' 34.7^{\prime \prime}$ \\
\hline 6 & 2013 & 13.27 & $01^{\circ} 58$ '54. & $117^{\circ} 2335.0^{\prime \prime}$ \\
\hline 8 & 2012 & 12.78 & $02^{\circ} 03^{\prime 26.2 "}$ & $117^{\circ} 26^{\prime 21.2 "}$ \\
\hline 10 & 2010 & 16.67 & $02^{\circ} 02^{\prime} 51.9^{\prime \prime}$ & $117^{\circ} 27^{\prime} 12.6^{\prime \prime}$ \\
\hline 12 & 2008 & 9.70 & $02^{\circ} 03^{\prime} 19.5^{\prime \prime}$ & $117^{\circ} 26^{\prime 23.3 "}$ \\
\hline
\end{tabular}

\section{Isolation of spores and root colonization}

Isolation of AMF spores was carried out by using the wetsieving and centrifugation methods described by Brundrett et al. (1996) with modifications. A $20 \mathrm{~g}$ soil sample was put into a measuring cup and water, and stirred for several minutes, then spilled into a spore filter $(500,125$, and $45 \mu \mathrm{m})$. Repeat the process until the suspension of the soil in the measuring cup is clear enough. Soil deposition contained in a 125 and 45 $\mu \mathrm{m}$ filter was moved into a centrifuge tube with the aid of a spatula and water. After that, add glucose solution to twothirds of the tube. The sample was centrifuged at a speed of $3000 \mathrm{rpm}$ (rotation per minute) for 3 minutes. The supernatant solutions were poured into filter paper and wait a few minutes for all the solutes to drop. After that, the filtered filter paper was transferred to a petri dish to calculated the number of spores.

The technique of root staining was done using the method of Clapp et al. (1996) with modifications. The roots were washed with water until cleaned, then soaked with $20 \% \mathrm{KOH}$ for two days (depending on plant roots). After that, the roots were washed by water, and soaked in $0.1 \mathrm{M} \mathrm{HCl}$ for 15 minutes. Subsequently, the roots were soaked again with a trypan blue dye solution for one day. The roots were washed again using water and soaked in a destaining solution overnight. Preparation begins with cutting the root $\pm 1 \mathrm{~cm}$ and was placed parallel to the object preparation. Each object preparation contained 10 pieces of root and every five pieces of the root were closed using a slipcover. Root colonization was calculated based on the appearance of AMF intraradical structure (hyphae, arbuscular, vesicles, and spores). The percentage of root colonization was determined using the formula Giovanenetti and Moose (1980). The following formula was used to calculate root colonization:

$$
\text { Root colonization }(\%)=\frac{\text { The total roots area infected }}{\text { The total roots planed observed }} \times 100 \%
$$

Percent colonization was then classified according to O'Connor et al. (2001), namely: (i) Not colonized: 0\% colonization, (ii) Low: colonization value $<10 \%$, (iii) Medium: $10-30 \%$ colonization value, (iv) High: colonization value> $30 \%$.

Table 2. Parameter and soil analysis methods

\begin{tabular}{|c|c|c|}
\hline Parameters & Analysis method & Unit \\
\hline $\mathrm{pH}$ & $\mathrm{H}_{2} \mathrm{O}$ & - \\
\hline C-organic & Walkley \& Black & $\%$ \\
\hline N-Total & Kjeldahl & $\%$ \\
\hline P-available & Bray I & ppm \\
\hline P-Total & HCL $25 \%$ & ppm \\
\hline $\mathrm{Ca}$ & $\mathrm{N} \mathrm{NH}_{4} \mathrm{OAc}$ pH 7.0 & $\mathrm{cmol}^{(+)} / \mathrm{kg}$ \\
\hline $\mathrm{Mg}$ & $N \mathrm{NH}_{4} \mathrm{OAc} \mathrm{pH} 7.0$ & $\mathrm{cmol}^{(+)} / \mathrm{kg}$ \\
\hline $\mathrm{K}$ & $\mathrm{N} \mathrm{NH}_{4} \mathrm{OAc}$ pH 7.0 & $\mathrm{cmol}^{(+)} / \mathrm{kg}$ \\
\hline $\mathrm{Na}$ & $N \mathrm{NH}_{4} \mathrm{OAc} \mathrm{pH} 7.0$ & $\mathrm{cmol}^{(+)} / \mathrm{kg}$ \\
\hline CEC & $N \mathrm{NH}_{4} \mathrm{OAc} \mathrm{pH} 7.0$ & $\mathrm{cmol}^{(+)} / \mathrm{kg}$ \\
\hline $\mathrm{Al}$ & $\mathrm{N} \mathrm{KCl}$ & $\mathrm{cmol}^{(+)} / \mathrm{kg}$ \\
\hline $\mathrm{H}$ & $\mathrm{N} \mathrm{KCl}$ & $\mathrm{cmol}^{(+)} / \mathrm{kg}$ \\
\hline $\mathrm{Fe}$ & DTPA & ppm \\
\hline Texture (sand, silt, and clay) & Metode pipet & $\%$ \\
\hline
\end{tabular}




\section{Data analysis}

Regression analysis was performed to determine the relationship between the number of spores with colonization. Meanwhile, Pearson correlation analysis was performed to determine the relationship between soil chemical properties and root colonization.

\section{RESULTS AND DISCUSSION}

\section{Soil properties}

The results showed that revegetation activities were able to increase the content of some nutrients in the soil (Table 3). Soil $\mathrm{pH}$ at the revegetation age ranges from 3.805.67 and was classified as very acidic and slightly acidic. The 10-year revegetation age class showed the highest $\mathrm{C}$ organic ( $3.58 \mathrm{~h})$, P-total (15.57ppm), and $\mathrm{Mg}(7.80 \mathrm{~h}$ ) values compared to other revegetation age classes. The $\mathrm{P}$ available and P-total content were very high in the six-year revegetation age class. Meanwhile, other elements differed between age classes revegetation. The content of $\mathrm{Al}$ and $\mathrm{Fe}$ was found to be highest in the 12-year revegetation age class compared to other revegetation age classes. Presumably, this was because the soil $\mathrm{pH}$ in the 12-year revegetation age class was classified as very acid (3.80). Meanwhile, soil texture in the revegetation age class was dominated by clay fraction $(34.36-43.30 \%)$, dust fraction (26.67-40.22\%), and a sand fraction (16.49-36.78\%).

\section{AMF population}

Result exhibited that the number of spores was present in the soil. The increase of the age revegetation class was able to increase the number of spores although this was not consistent. In the 10-year revegetation age class, the average number of spores decreased but increased again in the 12-year age class (Figure 1). Eight-year revegetation age classes showed the highest average number of spores compared to other revegetation age classes.

\section{Root colonization}

The types of plants in each revegetation age class indicate that they were colonized by AMF, although they differ between plant types and revegetation age classes (Table 4). F. moluccana and S. siamea were the dominant species, widely planted in the revegetation areas of the study site with an average of $32-44 \%$ and $12-20 \%$ respectively. A. mangium and G. cepium were species that grew naturally on post-coal mining land and showed $50 \%$ and $100 \%$ root colonization. G. cepium was the type with the highest root colonization compared to other types. The other types were insertions plant, planted in revegetation areas to increase the diversity of vegetation types and have different types of root colonization.

After observation, some of the understorey samples also showed the presence of root colonization by AMF (Table 5). Colonization of root plants was classified as moderate to high, while some species exhibited $100 \%$ root colonization such as $C$. pubescens, $U$. lobata, $P$. conjugatum, A. conyzoides, $M$. affine, and $P$. javanica. This situation revealed that plants have an important role in the development of AMF in the post-coal mining land.

Root colonization was very much influenced by propagules found in the soil. spores were one of the AMF propagules that can colonize the roots of the host plant. Regression analysis results showed that the number of spores had negative effect on root colonization $\left(\mathrm{R}^{2}=\right.$ $0.36 \%$ ) (Figure 2). Increasing the number of spores was not always able to increase root colonization by AMF.

Soil properties especially chemical properties affected root colonization by AMF. The results of the correlation analysis showed that the C-org, N-total, CEC, $\mathrm{Ca}, \mathrm{Mg}$, and $\mathrm{Fe}$ were positively correlated to root colonization, while available $\mathrm{P}$, total $\mathrm{P}, \mathrm{K}$, and $\mathrm{Al}$ were negatively correlated to root colonization (Table 6). $\mathrm{Mg}$ was one of the elements that correlate significantly with root colonization compared to other elements.

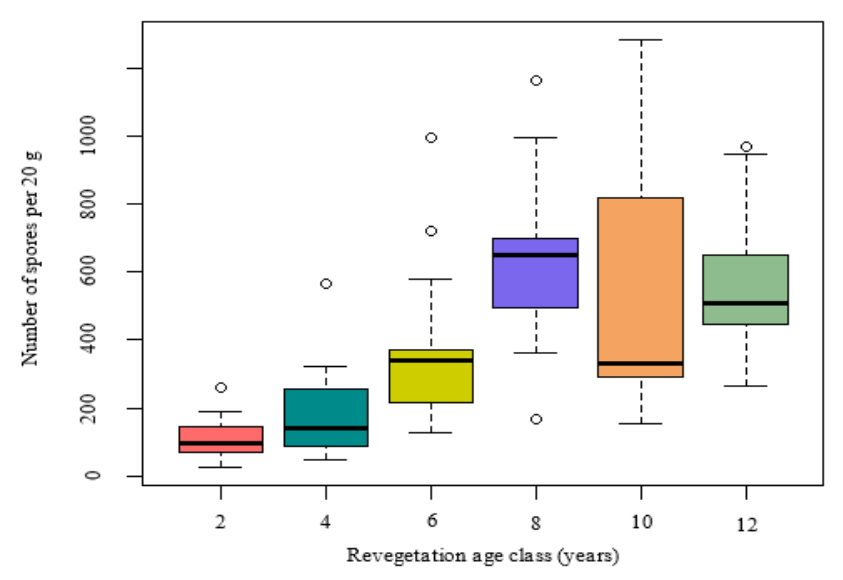

Figure 1. The number of spores in each revegetation age class

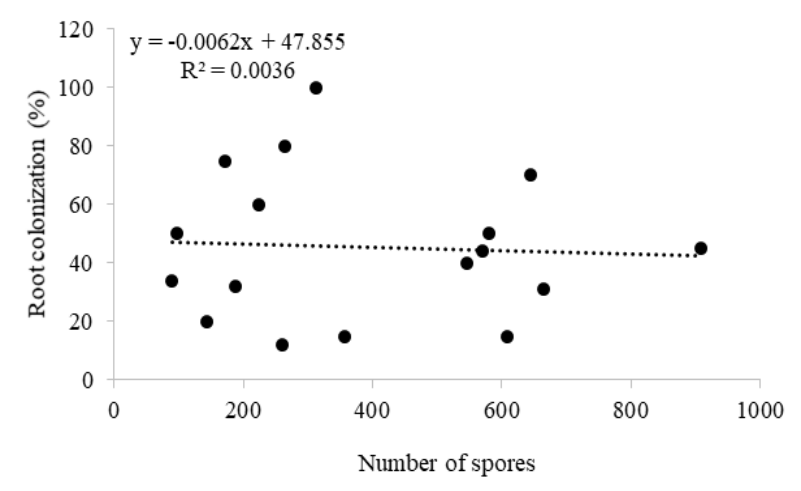

Figure 2. Relationship between number of spores and AMF root colonization 
Table 3. Characteristics of land in various age classes post-mining land revegetation of coal

\begin{tabular}{|c|c|c|c|c|c|c|}
\hline \multirow{2}{*}{ Parameters } & \multicolumn{6}{|c|}{ Revegetation age class (years) } \\
\hline & 2 & 4 & 6 & 8 & 10 & 12 \\
\hline $\mathrm{pH} \mathrm{H}_{2} \mathrm{O}$ & $5.67 \mathrm{ra}$ & $4.57 \mathrm{a}$ & $4.42 \mathrm{va}$ & $4.49 \mathrm{a}$ & 5.31ra & $3.80 \mathrm{va}$ \\
\hline C-org (\%) & 1.711 & 1.301 & $2.94 \mathrm{~m}$ & $2.62 \mathrm{~m}$ & $3.58 \mathrm{~h}$ & $3.38 \mathrm{~h}$ \\
\hline N-total $(\%)$ & 0.141 & 0.141 & $0.28 \mathrm{~m}$ & $0.26 \mathrm{~m}$ & $0.31 \mathrm{~m}$ & $0.32 \mathrm{~m}$ \\
\hline P-available (ppm) & $1.56 \mathrm{vl}$ & $1.74 \mathrm{vl}$ & $304.317 \mathrm{vh}$ & $8.60 \mathrm{~m}$ & 6.511 & 5.731 \\
\hline P-total (ppm) & $11.00 \mathrm{vl}$ & $8.06 \mathrm{vl}$ & $868.54 \mathrm{vh}$ & $10.72 \mathrm{vl}$ & 15.571 & $11.81 \mathrm{vl}$ \\
\hline $\mathrm{K}\left(\mathrm{cmol}^{(+)} / \mathrm{kg}\right)$ & $0.45 \mathrm{vl}$ & $0.24 \mathrm{vl}$ & $0.88 \mathrm{vl}$ & $0.61 \mathrm{vl}$ & $0.59 \mathrm{vl}$ & $0.40 \mathrm{vl}$ \\
\hline $\mathrm{Ca}\left(\mathrm{cmol}^{(+)} / \mathrm{kg}\right)$ & $12.46 \mathrm{~h}$ & 4.661 & 4.431 & 2.691 & $7.95 \mathrm{~m}$ & 2.201 \\
\hline $\mathrm{Mg}\left(\mathrm{cmol}^{(+)} / \mathrm{kg}\right)$ & $3.41 \mathrm{~h}$ & $3.35 \mathrm{~h}$ & $2.09 \mathrm{~h}$ & $3.59 \mathrm{~h}$ & $7.80 \mathrm{~h}$ & $2.92 \mathrm{~h}$ \\
\hline $\mathrm{CEC}\left(\mathrm{cmol}^{(+)} / \mathrm{kg}\right)$ & 13.461 & 15.491 & $17.22 \mathrm{~m}$ & $22.62 \mathrm{~m}$ & $21.22 \mathrm{~m}$ & $17.24 \mathrm{~m}$ \\
\hline $\mathrm{Al}\left(\mathrm{cmol}^{(+)} / \mathrm{kg}\right)$ & $\mathrm{nm}$ & 0.64 & 1.59 & 1.60 & $\mathrm{~nm}$ & 2.24 \\
\hline $\mathrm{Fe}(\mathrm{ppm})$ & $70.43 \mathrm{vh}$ & $80.52 \mathrm{vh}$ & $169.70 \mathrm{vh}$ & $140.85 \mathrm{vh}$ & $156.43 \mathrm{vh}$ & $477.33 \mathrm{vh}$ \\
\hline Sand $(\%)$ & 34.38 & 32.36 & 32.02 & 16.49 & 36.78 & 37.75 \\
\hline Silt $(\%)$ & 26.67 & 32.75 & 30.18 & 40.22 & 28.86 & 28.22 \\
\hline Clay $(\%)$ & 38.95 & 34.89 & 37.81 & 43.30 & 34.36 & 34.02 \\
\hline
\end{tabular}

Note: CEC (cation exchange capacity); ra (rather acid); a (acid); va (very acid): 1 (low); vl (very low); m (medium); h (high); vh (very high); nm (not measurable). The criteria for soil properties are based on Eviati and Sulaeman (2009)

Table 4. The average root colonization of plant in various age classes of revegetation

\begin{tabular}{llll}
\hline $\begin{array}{l}\text { Revege- } \\
\text { tation } \\
\text { age class } \\
\text { (years) }\end{array}$ & Species & $\begin{array}{l}\text { Average } \\
\text { colonization } \\
(\%)\end{array}$ & Criteria \\
\hline 2 & Falcataria moluccana & 34 & High \\
& Senna siamea & 25 & Medium \\
& Swietenia macrophylla & 50 & High \\
4 & Falcataria moluccana & 32 & High \\
& Senna siamea & 15 & Medium \\
& Acacia mangium & 75 & High \\
6 & Senna siamea & 22.86 & Medium \\
& Shorea leprosula & 50 & High \\
8 & Senna siamea & 14.55 & Medium \\
& Acacia mangium & 45 & High \\
10 & Senna siamea & 31.11 & High \\
& Shorea leprosula & 70 & High \\
& Enterolobium cylocarpum & 60 & High \\
& Glirisida cepium & 100 & High \\
12 & Falcataria moluccana & 44 & High \\
& Vitex cofasus & 80 & High \\
& Neolamarcia cadamba & 40 & High \\
& Dryobalanops lanceolata & 20 & Medium \\
\hline Note: Colonization criteria based on O'Connor et al. (2002)
\end{tabular}

\section{Discussion}

At the beginning of the age class of revegetation, soil fertility was relatively low, as indicated by several nutrients that were relatively low.. The variation of soil properties on post-mining land was strongly influenced by origin condition of the mine soil itself (Zipper et al. 2011).

Soil $\mathrm{pH}$ affects the availability of some nutrients in the soil. Ezeokoli et al. (2019) also reported that the average soil $\mathrm{pH}$ on reclaimed land after coal mining has acidic (4.03-4.89). Acidic soil $\mathrm{pH}$ to very acidic in post-mining land was strongly influenced by the condition of host rock that makes up the soil itself. The $\mathrm{pH}$ of acid soils on post-
Table 5. The average root colonization of understorey in various age classes of revegetation

\begin{tabular}{llll}
\hline $\begin{array}{l}\text { Revege- } \\
\text { tation } \\
\text { age class } \\
\text { (years) }\end{array}$ & Species & $\begin{array}{l}\text { Average } \\
\text { colonization } \\
(\boldsymbol{\%})\end{array}$ & Criteria \\
2 & Centrosema pubescens & 100 & High \\
& Mucuna mucronata & 90 & High \\
& Urena lobata & 100 & High \\
& Paspalum conjugatum & 70 & High \\
4 & Ageratum conyzoides & 75 & High \\
6 & Paspalum conjugatum & 100 & High \\
& Rhyncospora corymbosa & 60 & High \\
& Ageratum conyzoides & 100 & High \\
& Melastoma affine & 70 & High \\
& Melastoma affine & 100 & High \\
& Nephrolepis biserrata & 20 & Medium \\
& Melastoma malabatricum & 60 & High \\
10 & Chromolaena odorata & 60 & High \\
& Pueraria javanica & 100 & High \\
& Paspalum conjugatum & 100 & High \\
& Ageratum conyzoides & 40 & High \\
& Digitaria bicornis & 10 & Medium \\
& Nephrolepis biserrata & 20 & Medium \\
& Melastoma affine & 20 & Medium \\
12 & Ageratum conyzoides & 100 & High \\
\hline Note: Colonization criteria based on O'Connor et al 2002)
\end{tabular}

Note: Colonization criteria based on O'Connor et al. 2002)

mining coal also due to concentrations of pyrite (FeS2) that were significantly higher in the soil (Rai and Paul 2011). Mine soil $\mathrm{pH}$ can change quickly when the rock was split and oxidized (Sheoran et al. 2010). High rainfall can lead to the leaching of the alkaline cation $\left(\mathrm{K}^{+}, \mathrm{Na}^{+}, \mathrm{Ca}^{2+}\right.$, and $\mathrm{Mg}^{2+}$ ) that contribute to soil acidity (Seguel et al. 2013). Besides, the coal reacting with rainwater was able to produce $\mathrm{Fe}, \mathrm{Al}$ and $\mathrm{Mn}$ (heavy toxic metals) which generate quite high acidity (Agus et al. 2016; Sheoran et al. 2010). Fe content was very high in all revegetation age classes (Kusmana et al. 2013) reported that the $\mathrm{Al}$ and Fe content were quite high in post-coal mining land in South Kalimantan. 
Tabel 6. Correlation of soil chemical properties with root colonization

\begin{tabular}{lc}
\hline \multicolumn{1}{c}{ Parameters } & Root colonization \\
\hline C-organic & 0.533 \\
N-total & 0.438 \\
P-available & -0.333 \\
P-total & -0.331 \\
$\mathrm{~K}$ & -0.157 \\
$\mathrm{Ca}$ & 0.160 \\
$\mathrm{Mg}$ & $0.861^{*}$ \\
$\mathrm{CEC}$ & 0.272 \\
$\mathrm{Al}$ & -0.934 \\
$\mathrm{Fe}$ & 0.231 \\
\hline Note: *: correlation is significant at the 0.05 level
\end{tabular}

The content of $\mathrm{C}$-organic increases in revegetation age classes, especially in the eight and 12 years revegetaion classes. This was due to new input of carbon content released by the plant and decomposition of many litters (Ahirwal et al. 2017). Soil organic carbon has strongly affected by litter decomposition, crop productivity, and revegetation age (Singh et al. 2004). Ahirwal et al. (2017) reported that soil organic carbon increased after eight years of revegetation. Soil organic carbon and nitrogen have increased along with the increasing age of reclamation after coal mining (Wick et al. 2009: Reynolds and Reddy 2012). The availability of nitrogen in the soil has greatly influenced by the presence of organic matter (litter) which decomposed and mixed with the soil (Chaubey et al. 2012)

The P-available and P-total content in the revegetation age class was much higher in the six-year revegetation age class. Salim et al. (2019) reported that the content of P-total at some revegetation age class is high to very high. The Pavailable content is strongly influenced by the content of organic matter, the higher the organic material will increase the availability of P-available (Chaubey et al. 2012). The high P-available content was due to the high activity of acid phosphatase in the soil, so that insoluble phosphorus in the soil became available for plants (Bi et al. 2018).

Soil texture in various revegetation age classes was dominated by clay fraction. This result follows the research of Agus et al. (2018) who reported that land on coal mining areas in East Kalimantan was dominated by clay $(32.439 .44 \%)$, sand $(24.7-37.3 \%)$ and dust (28.8$36.5 \%)$. Singh et al. (2004) reported that the lowest clay content was around $11 \%$ and maximum sand was $80 \%$. Post-mining land conditions can recover along with increasing age of revegetation (Hazarika et al. 2006; Chandra 2014).

The AMF population increased along with increasing of revegetation, but the increase was still inconsistent. Casazza et al. (2017) stated that the composition and diversity of AMF was different for each location. The differences between host plant, location, and root rhizosphere can influence the AMF population in the soil (Husna et al. 2015; Rahim et al. 2016). Soil properties that varied in each revegetation age classes and plant types (also affected different AMF spores. The availability of nutrients in the soil can change the abundance and diversity of AMF (Camenzind et al. 2014; Lekberg et al. 2007). The formation of spores was also influenced by the physical and chemical properties of the soil (Chandra 2014). Revegetation activities can facilitate the development of $\mathrm{AMF}$ on post-mining land (Li 2006). Several studies indicate that there was a change in the composition of the AMF community during ecosystem development (Sikes et al. 2009; Martínez-García et al. 2015). The presence of AMF populations plays an important role in the formation and growth of plants, especially in post-coal fields have low soil fertility (Singh and Jamaluddin 2011).

Each plant in each revegetation age class shows that it has been colonized by AMF (although it varies.. Plant species found above ground level can be the host for the survival of $\mathrm{AMF}(\mathrm{Ong}$ et al. 2012). Host plants provide a habitat and food supply for soil microbes that live around the rhizosphere (Akib et al. 2018). According to Becklin et al. (2012), trees were indirectly able to interact with another plantin influencing the composition and diversity of AMF in the soil. Each type of plant can produce different levels of colonization by AMF (Berruti et al. 2016; Bi et al. 2018).

Some of the dominant species and understorey plants on post-coal mining land were those of Fabaceae or Leguminoceae such as $F$. moluccana, A. mangium, $S$. Siamea, C. pubescens, P. Javanica, and M. Mucronata. Wulandari et al. (2016) reported that the Paraserianthes falcataria plant had $59 \%$ root colonization which was planted in the post-coal field. Legume plants were responsive to associations with AMF especially in soils with low $\mathrm{P}$ availability, which will affect the performance of the plant growth (Kumar et al. 2010).

The average percentage of understorey AMF root colonization was higher than that of staple. Roumet et al. (2006) stated that the root system greatly affects the percentage of root colonization and affects dependence on mycorrhizae. Closa and Goicoechea (2011) reported that the colonization percentage of annual plant roots (Meehringia trinervia) was lower than that of grass species (B. pinnatum and $F$. rubra) which grew in disturbed forests. However, in some cases, the colonization rate of annual plant roots was higher than that of perennial plants (Roumet et al. 2006). Cheeke et al. (2019) reported that grassland plant species in late succession were very responsive to $\mathrm{AMF}$ and showed quite strong sensitivity.

Spores were one of the AMF propagules that can colonize the roots of the host plant. The source of inoculum which can cause root infection by AMF consists of hyphae, and infected parts of the root (Smith and Read 2008; Silvana et al. 2018). The presence of spores greatly affects the colonization of roots. Increased spore production in the soil can increase the root colonization of AMF (Cuenca and Lovera 2010). The regression analysis showed that the number of spores had a negative relationship with root colonization. The percentage of root colonization was inversely proportional to the AMF spore population in some ecosystems (Moreira et al. 2006). Zangaro et al. (2012) reported that increasing the number of spores can increase root colonization. Husna et al. (2015) reported that spore density was not correlated with AMF colonization. 
The analysis showed that root colonization by AMF had a positive correlation with carbon organic, N-total, CEC, and $\mathrm{Fe}$, while it was negatively correlated with available $\mathrm{P}$, total $\mathrm{P}, \mathrm{K}$, and $\mathrm{Al}$. Carbon organic was able to trigger the presence of AMF in the soil and become a food source for soil microorganisms (Thirkell et al. 2016). The organic carbon has a strong correlation with the number of spores (Bath et al. 2014).) The percentage of AMF colonization was positively correlated with soil organic matter (Silvana et al. 2018; Silvana et al. 2018). According to Melo et al. (2019) root colonization by AMF was influenced by soil $\mathrm{pH}$, available $\mathrm{P}, \mathrm{K}$ and $\mathrm{Mg}$. The level of root colonization by AMF was also influenced by the level of soil fertility (Martinez and Johnson 2010; Nyamwange et al. 2018). $t$ AMF root colonization had a positive correlation with tanh $\mathrm{pH}, \mathrm{Ca}, \mathrm{K}$ and $\mathrm{Ca} / \mathrm{Mg}$ ratio in serpentine soil has been reported by Doubková et al. (2011). Mg was one of the elements that have a significant positive correlation. $\mathrm{Mg}$ was a nutrient capable of developing mycorrhizae in the roots (Saleh Rastin 2001). Ardestani et al. (2011) reported that $\mathrm{Mg}$ was able to increase root colonization by AMF to a certain concentration (up to $7.2 \mathrm{meq} / \mathrm{l}$ ), but could reduce the AMF colonization when the concertration of $\mathrm{Mg}$ is too high. In in vitro, $1.5 \mathrm{mM} \mathrm{Mg}$ was able to inhibit the growth of Glomus claroideum hyphae, but did not affect root colonization. (Malcová et al. 2002). Zhang et al. (2015) reported that root colonization by AMF was significantly higher in Mg deficiency conditions, this shows that root colonization by $\mathrm{AMF}$ has a negative correlation with $\mathrm{Mg}$ concentration.

$\mathrm{P}$-available and P-total have negative correlation with root colonization by AMF. Lakshmipathy et al. (2012) reported that AMF activity has a negative correlation between P-available and P-total. High availability of $\mathrm{P}$ in the soil can reduce root colonization by AMF and spore production (Gosling et al. 2013; Kowalska et al. 2015; Schmitd et al. 2010; Smith and Smith 2011). The reduction of phosphorus elements in the soil can increase root colonization by Rhizopagus irregularis (Bonneau et al. 2013). Soka et al. (2015) also reported that increasing $P$ was able to reduce hyphal density. Besides, the number of spores was also high at the low P-available conditions (Birhane et al. 2010; Tian et al. 2011). The results of Kowalska and Konieczny's (2015) report that high $\mathrm{P}$ concentrations $\left(140 \mathrm{mg} \mathrm{dm}^{-3}\right)$ have a negative impact on the development of mycorrhizal structures, but $\mathrm{P}$ concentration $\left(70 \mathrm{mg} \mathrm{dm}^{-3}\right)$ have a positive on the development of mychorrizal structures. However, the results of Zangaro et al. (2013) reported that root colonization by AMF had a positive correlation with $\mathrm{P}$ in the soil.

Potassium (K) also has a negative correlation with the percentage of root colonization by AMF. These results are consistent with several studies which show that the potassium in the soil has a negative correlation with root colonization by AMF (Ardestani et al. 2011; Melo et al. 2019; Panwar et al. 2011). However, in some cases potassium can stimulate and increase the rate of root colonization by AMF (Melo et al. 2019; Zhang et al. 2017). Potassium can increase root colonization by AMF in drought conditions (Melo et al. 2019; Zhao et al. 2017). Potassium was not able to increase the rate of AMF root colonization, but was only able to increase the length of the roots colonized by AMF. (El-Mesbahi et al. 2012). Each plant has a different AMF response to root colonization. AMF spore population which is pretty much not always able to increase root colonization. Soil chemical properties can affect the root colonization by AMF, especially Mg.

\section{ACKNOWLEDGEMENTS}

This research was funded by the Ministry of Education and Culture, Directorate General of Higher Education, Republic of Indonesia with the scheme of Penelitian Pendidikan Magister menuju Doktor untuk Sarjana Unggul (PMDSU). We would like to thank PT Berau Coal which has given permission for the research location.

\section{REFERENCES}

Agus C, Primananda E, Faridah E, Wulandari D, Lestari T. 2018. Role of arbuscular mycorrhizal fungi and Pongamia pinnata for revegetation of tropical open-pit coal mining soils. Int J Environ Sci Technol 16 (7): 3365-3374

Agus C, Putra PB, Faridah E, Wulandari D, Napitupulu RNP. 2016. Organic carbon stock and their dynamics in rehabilitation ecosystem areas of post open coal mining at tropical region. Procedia Eng 159: 329-337.

Ahirwal J, Maiti SK, Reddy MS. 2017. Development of carbon, nitrogen and phosphate stocks of reclaimed coal mine soil within 8 years after forestation with Prosopisjuliflora (Sw.) Dc. Catena 165: 42-50.

Akib MA, Mustari K, Kuswinanti T, Syaiful SA. 2018. Abundance of arbuscular mychorrizal fungi rehabilitation ara of nickel post-mining land of Sorowako, South Sulawesi. IOP Conf Ser: Earth Environ Sci 157. DOI: 10.1088/1755-1315/157/1/012022.

Akiyama K, Matsuzaki K, Hayashi H. 2005. Plant sesquiterpenes induce hyphal branching in arbuscular mycorrhizal fungi. Nature 435: 824827.

Ardestani NK, Zare-Maivan H, Ghanati F. 2011. Effect of different concentrations of potassium and magnesium on mycorrhizal colonization of maize in pot culture. Afr J Biotechnol 10 (73): 1654816550 .

Asmelash F, Bekele T, Birhane E. 2016. The potential role of arbuscular mycorrhizal fungi in the restoration of degraded lands. Front Microbiol 7: 1095.

Balestrini R, Magurno F, Walker C, Lumini E, Bianciotto V. 2010. Cohorts of arbuscular mycorrhizal fungi (AMF) in Vitis vinifera, a typical Mediterranean fruit crop. Environ Microbiol Rep 2: 594-604.

Balestrini R, Lumini E, Borriello R, Bianciotto V. 2015. Plant-soil biota interactions. In: Paul EA (eds) Soil Microbiology, Ecology and Biochemistry. Academic Press, Elsevier, London. DOI: 10.1016/b978-0-12-415955-6.00011-6.

Banerjee K, Gadani MH, Srivastava KK, Verma N, Jasrai YT, Jain NK. 2013. Screening of efficient arbuscular mycorrhizal fungi for Azadirachta indica under nursery condition: a step towards afforestation of semi-arid region of western India. Braz J Microbiol 44 (2): 587-593.

Banuelos J, Alarcón A, Larsen J, Cruz-Sánchez, Trejo. 2014. Interactions between arbuscular mycorrhizal fungi and Meloidogyne incognita in the ornamental plant Impatiens balsamina. J Soil Sci Plant Nutr 14 (1): 63-74.

Bath BA, Sheikh M, Tiwari A. 2014. Impact of various edaphic factors on AMF spore population and diversity in Catharanthus roseus at Gwalior. Intl J Plant Sci 9 (1): 1-6.

Becklin KM, Pallo ML, Galen C. 2012. Willows indirectly reduce arbuscular mycorrhizal fungal colonization in understorey communities. J Ecol 100: 343-351. 
Bhuvaneswari G, Reetha S, Sivaranjani R, Ramakrishnan K. 2014. Effect of AM fungi and Trichoderma species as stimulations of growth and morphological character of chilli (Capsicum annum L.). Intl J Curr Microbiol Appl Sci (3): 447-455.

Bi Y, Zhang Y, Zou H. 2018. Plant growth and their root development after inoculation of arbuscular mycorrhizal fungi in coal mine subsided areas. Int J Coal Sci Technol 5 (1): 47-53.

Bonneau L, Huguet S, Wipf D, Pauly N, Truong HN. 2013. Combined phosphate and nitrogen limitation generates a nutrient stress transcriptome favorable for arbuscular mycorrhizal symbiosis in Medicago truncatula. New Phytol 199: 188-202.

Brundrett MC, Bougher N, Dells B, Grove T, Malajozuk N. 1996 Working with mycorrhizas in forestry and agriculture. Australian Centre for International Agricultural Research, Australia.

Cabral L, Soares CLRFS, Giachini AJ, Siqueira. 2015. Arbuscular mycorrhizal fungi in phytoremediation of contaminated areas by trace elements: mechanisms and major benefits of their applications. World J Microbial Biotchnol 31 (11): 1655-1664. DOI: 10.1007/s11274015-1918-y

Camenzind T, Hempel S, Homeier J, Horn S, Velescu A, Wilcke W, Rillig MC. 2014. Nitrogen and phosphorus additions impact arbuscular mycorrhizal abundance and molecular diversity in a tropical montane forest. Glob Chang Biol 20 (12): 3646-3659.

Casazza G, Lumini E, Ercole E, Dovana F, Guerrina, Arnulfo A, Minuto L, Fusconi A, Mucciarelli. 2017. The abundance and diversity of arbuscular mycorrhizal fungi are linked to the soil chemistry of screes and to slope in the Alpic paleo-endemic Berardia subacaulis. PLoS ONE 12 (2): e0171866. DOI: 10.1371/journal.pone.0171866.

Chairul, Noli ZA, Suwirmen, Syamsuardi, Reini. 2019. Exploration of indigenous arbuscular mycorrhizal fungi on post mining soil as rehabilitation strategy. J Biol Sci 19: 218-223.

Chandra KK. 2014. Recovery pattern in diversity and species of ground vegetation and $A M F$ in reclaimed coal mine dumps of Korba (India). Expert Opin Environ Biol 4: 1. DOI: 10.4172/2325-9655.1000110.

Chaubey OP, Bohre P, Singhal PK. 2012. Impact of bio-reclamation of coal mine spoil on nutritional and microbial characteristics. Intl J BioSci Bio-Technol 4 (3): 69-79.

Cheeke TE, Zheng C, Koziol L, Gurholt CR, Bever JD. 2019. Sensitivity to AMF species is greater in late-successional than early-successional native or nonnative grassland plants. Ecology 100 (12): e02855. DOI 10.1002/ecy.2855.

Clapp JP, Fitter AH, Merryweather JM. 1996. Arbuscular mychorriza. In Hall GS, Lassere P, Hawwksworth DL (eds.). Methods for the Examination of Organismal Diversity in Soil and Sediments. CAB Internasional, Wallingford, UK

Closa I, Goicoechea. Infectivity of arbuscular mycorrhizal fungi in naturally regenerating, unmanaged and clear-cut beech forests. Pedosphere 21 (1): 65-74.

Cuenca G, Lovera M. 2010. Seasonal variation and distribution at different soil depths of arbuscular mycorrhizal fungi spores in a tropical sclerophyllous shrubland. Botany 88: 54-64.

Davison J, Moora M, Öpik M, Adholeya A, Ainsaar L, Bâ, Burla S, Dheidiou, Hiiesalu I, Jairus T et al. 2015. Global assessment of arbuscular mycorrhizal fungus diversity reveals very low endemism. Science 349 (6251): 970-973.

Doubková P, Suda J, Sudová R. 2011. Arbuscular mycorrhizal symbiosis on serpentine soils: the effect of native fungal communities on different Knautia arvensis ecotypes. Plant Soil 345: 325-338.

El-Mesbahi MN, Azcón R, Ruiz-Lozano JM, Aroca R. 2012. Plant potassium content modifies the effects of arbuscular mycorrhiza symbiosis on root hydraulic properties in maize plants. Mycorrhiza 22: 555-564.

Ezeokoli OT, Mashigo SK, Maboeta MS, Bezuidenhout CC, Khasa DP Adeleke RA. 2019. Arbuscular mycorrhizal fungal community differentiation along a post-coal mining reclamation chronosequence in South Africa: a potential indicator of ecosystem recovery. Appl Soil Ecol 147: 103429.

Eviati, Sulaeman. 2009. Chemical analysis of soil, plant, water, and fertilizer. Indonesian Soil Research Institut, Bogor. [Indonesian]

Giovannetti M, Moose B. 1980. An evaluation of technique for measuring vesicular-arbuscular mycorrhizal infection in roots. New Physiol 84 489-500

Goltapeh EM, Danesh YR, Varma A. 2013. Fungi as Bioremediators (eds.) Soil Biology. Springer, Heidelberg.

Gosling P, Mead A, Proctor M, Hammond JP, Bending GD. 2013 Contrasting arbuscular mycorrhizal communities colonizing different host plants show a similar response to a soil phosphorus concentration gradient. New Phytol 198 (2): 546-556.

Gosling P, Jones J, Bending GD. 2016. Evidence for functional redundancy in arbuscular mycorrhizal fungi and implications for agroecosystem management. Mycorrhiza 26 (1): 77-83.

Hazarika P, Talukdar NC, Singh YP. 2006. Natrual colonization of plant species on coal mine spoils at Tikak Colliery, Assam. Trop Ecol 47 (1): $37-46$.

Husin EF, Khairul U, Zakir Z, Emalinda E. 2017. Spores diversity of arbuscular mycorrhizal fungi and their use for land reclamation in coal mining used land. Der Pharm Lett 9 (2): 79-86.

Husna, Budi SW, Mansur I, Kusmana C. 2015. Diversity af Arbuscular mycorrhizal fungi in the growth habitat of kayu kuku (Pericopsis mooniana Thw.) in Southeast Sulawesi. Pak J Biol Sci 18 (1): 1-10.

Husna, Budi SW, Mansur I, Kusmana C. 2016. Growth and nutrient status of kayu kuku [Pericopsis mooniana (Thw.) Thw] with mycorrhiza in soil media of nickel post mining site. Pak J Biol Sci 19: 158-170.

Husna, Mansur I, Budi SW, Tuheteru FD, Arif A, Tuheteru EJ, Albasri. 2019. Effects of arbuscular mycorrhizal fungi and organic material on growth and nutrient uptake by Pericopsis mooniana in coal mine. Asian J Plant Sci 18 (3): 101-109.

Husna, Tuheteru FD, Arif A. 2020. The potential of arbuscular mycorrhizal fungi to conserve Kalappia celebica, an endangered endemic legume on gold mine tailings in Sulawesi, Indonesia. J For Res 1:1-8. DOI: 10.1007/s11676-020-01097-8.

Janoušková M, Krak K, Vosátka M, Püschel D, Štorchová H. 2017. Inoculation effects on root-colonizing arbuscular mycorrhizal fungal communities spread beyond directly inoculated plants. PLoS ONE 12 (7): e0181525. DOI: 10.1371/journal.pone.0181525.

Kowalska I, Konieczny A, Gastol M, Sady W, Hanus-Fajerska. 2015. Effect of mycorrhiza and phosphorus content in nutrient solution on the yield and nutritional status of tomato plants grown on rockwool or coconut coir. Agric Food Sci 24 (1): 39-51.

Krüger C, Kohout P, Janoušková1 M, Püschel1 D, Frouz J, Rydlová1 J. 2017. Plant communities rather than soil properties structure arbuscular mychorrizal fungal communities along primery succession on a mine spoil. Fron Microbiol 8: 719. DOI: 10.3389/fmicb.2017.00719.

Kumar A, Raghuwanshi R, Upadhyay RS. 2003. Vasicular-arbuscular mychorrizal association in naturally revegetated coal mine spoil. Trop Ecol 44 (2): 253-256.

Kumar A, Mangla C, Aggarwal A, Parkash V. 2010. Arbuscular mycorrhizal fungal dynamics in the rhizospheric soil of five medicinal plant species. Middle East J Sci Res 6 (3): 281-288.

Kusmana C, Setiadi Y, Al-Anshary MAL. 2013. Study of plant growth as a result of revegetation in coal ex-mined land PT. Arutmin Indonesia Site Batulicin South Kalimantan. Jurnal Silvikultur Tropika 4 (3):160165. [Indonesian]

Latef AAHA, Chaoxing H. 2011. Effect of arbuscular mycorrhizal fungi on growth, mineral nutrition, antioxidant enzymes activity and fruit yield of tomato grown under salinity stress. Sci Hortic 127 (3): 228233.

Lakshmipathy R, Balakrishna AN, Bagyaraj DJ. 2012. Abundance and diversity of AM fungi across a gradient of land use intensity and their seasonal variations in Niligiri Biosphere of the Western Ghats, India. J Agric Sci Tech 14: 903-918

Lekberg Y, Koide RT, Rohr JR, Aldrich-Wolfe L, Morton JB. 2007. Role of niche restrictions and dispersal in the composition of arbuscular mycorrhizal fungal communities. J Ecol 95: 95-105.

Li MS. 2006. Ecological restoration of mineland with particular reference to the metalliferous mine wasteland in China: a review of research and practice. Sci Total Environ 357: 38-53.

Malcová R, Gryndler M, Vosátka M. 2002. Magnesium ions alleviate the negative effect of manganese on Glomus claroideum BEG23. Mycorrhiza 12: 125-129.

Martinez TN, Johnson NC. 2010. Agricultural management influences propagule densities and functioning of arbuscular mycorrhizas in lowand high- input agroecosystems in arid environments. Appl Soil Ecol 46: $300-306$.

Martinez-Garcia LB, Richardson SJ, Tylianakis JM, Peltzer DA, Dickie IA. 2015. Host identity is a dominant driver of mycorrhizal fungal community composition during ecosystem development. New Phytol 205: 1565-1576.

Matthiasc R, Noorf M, Evaf L, Pedrom A. 2010. Mycelium of arbuscular mycorrhizal fungi increases soil water repellency and is sufficient to 
maintain water-stable soil aggregates. Soil Biol Biochem 42 (7): 1189-1191.

Melo CD, Walker C, Krüger C, Borges PAV, Luna S, Mendonca D, Fonseca HMAC, Machando AC. 2019. Environmental factors driving arbuscular mycorrhizal fungal communities associated with endemic woody plant Picconia azorica on native forest of Azores. Ann Microbiol 69: 1309-1327.

Moreira M, Barret D, Tsai SM, Cardoso EJBN. 2006. Spore density and root colonization by arbuscular mychorrizal fungi in preserved or disturbed Araucaria angustifolia (Bert.) O. Ktze. ecosystems. Scientia Agricola 63 (4): 380-385

Mushia NM, Ramoelo A, Ayisi KK. 2016. The impact of the quality of coal mine stockpile soils on sustainable vegetation growth and productivity. Sustainability 8 (6): 546.

Musyoka DM, Njeru EM, Nyamwange MM, Maingi JM. 2020. Arbuscular mycorrhizal fungi and Bradyrhizobium coinoculation enhances nitrogen fixation and growth of green grams (Vigna radiata L.) under water stress. J Plant Nutr 43 (7): 1036-1047. DOI: 10.1080/01904167.2020.1711940.

Novazio L, Moscatiello R, Genre A, Novero M, Baldan B, Bofante P, Mariani. 2007. A diffusible signal from arbuscular mycorrhizal fungi elicits a transient cytosolic calcium elevation in host plant cells. Plant Physiol 144: 673-681.

Nyamwange MM, Njeru EM, Mucheru-Muna, Ngetich F. 2018. Soil management practices affect arbuscular mycorrhizal fung propagules, root colonization and growth of rainfed maize. AIMS Agric Food 3 (2): 120-134.

O'connor PJ, Smith SE, Smith FA. 2001. Arbuscular mycorrhizal association in the Southern Simpson desert. Aust J Bot 49: 493-499.

Ong KH, Chubo JK, King JH, Le CS, Su DSA, Sipen P. 2012. Influence of soil chemical properties on relative abundance of arbuscular mycorrhiza in forested soils in Malaysia. Turk J Agric For 36: 451458.

Oyewole BO, Olawuyi OJ, Odebode AC, Abiala MA. 2017. Influence of arbuscular mycorrhiza fungi (AMF) on drought tolerance and charcoal rot disease of cowpea. Biotechnol Rep 14: 8-15.

Panwar V, Meghvansi MK, Siddiqui S. 2011. Short-term tempora variation in sporulation dynamics of arbuscular mycorrhizal (AM) fungi and physico-chemical edaphic properties of wheat rhizosphere. Saudi J Biol Sci 18: 247-254.

Pinos NQ, Berbara RLL, Elias SS, de Castro TAVT, García. 2019. Combination of humic substances and arbuscular mycorrhizal fungi affecting corn plant growth. J Environ Qual 48: 1594-1604.

Polcyn W, Paluch-Lubawa E, Lehmann T, Mikuła R. 2019. Arbuscular mycorrhiza in highly fertilized maize cultures alleviates short-term drought effects but does not improve fodder yield and quality. Front Plant Sci 10: 496. DOI: 10.3389/fpls.2019.00496.

Porcel R, Redondo-Gómez S, Mateos-Naranjo E, Aroca R, Garcia R, Ruiz-Lozano JM. 2015. Arbuscular mycorrhizal symbiosis ameliorates the optimum quantum yield of photosystem II and reduces non-photochemical quenching in rice plants subjected to salt stress. J Plant Physiol 185: 75-83.

Prayudyaningsih R, Sari R, Mangopangi AD. 2018. Isolation of Iindigenous arbuscular mycorrhizal fungi (AMF) to suppor revegetation on the nickel post-mining land. IOP Conf Ser: Earth Environ Sci 308: 012038. DOI: 10.1088/1755-1315/308/1/012038.

Rahim NA, Jais HM, Hassan HM. 2016. Environment and host affects arbuscular mycorrhiza fungi (AMF) population. Trop Life Sci Res 27 (1): 9-13.

Rajtor M, Piotrowska-Seget Z. 2016. Prospects for arbuscular mycorrhizal fungi (AMF) to assist in phytoremediation of soil hydrocarbon contaminants. Chemosphere 162: 105-116.

Reynolds B, Reddy KJ. 2012. Infiltration rates in reclaimed surface coal mines. Water Air Soil Pollut 223 (9): 5941-5958.

Rillig MC, Aguilar-Trigueros CA, Bergmann J, Verbruggen E, Veresoglou SD, Lehmann A. 2015. Plant root and mycorrhizal fungal traits for understanding soil aggregation. New Phytol 205: 1385-1388.

Roumet C, Urcelay C, Díaz, S. 2006. Suites of root traits differ between annual and perennial species growing in the field. New Phytol 170: 357-368

Sahner J, Budi SW, Barus H, Edy N, Meyer M, Corre MD, Polle A. 2015. Degradation of root community traits as indicator for transformation of tropical lowland rain forest into oil palm and rubber plantations. PloS ONE 10 (9): 1-19. DOI: 10.1371/journal.pone.0138077.

Saleh Rastin N. 2001. Biological fertilizer and their role in achieving sustainable agriculture. In: Klavazi K, Malakouti J (eds) Necessity for the production and biofertilizer in Iran: A compliation of papers. Nashr Amouzesh Keshavarzi publishers, Tehran, Iran.

Salim MA, Budi SW, Setyaningsih L, Iskandar, Kirmi H. 2019. Diversity of arbuscular mycorrhizal fungi as affected by time consequences revegetation age in post coal mine area at PT Berau Coal Tbk, East Kalimantan Indonesia. IOP Conf Ser: Earth Environ Sci 394 (1): 012067. DOI: 10.1088/1755-1315/394/1/0120672.

Schmidt B, Domonkos M, Sumălan RL, Biró B. 2010. Suppression of arbuscular mycorrhiza's development by high concentration of phosphorous at Tagetes patula L. Res J Agric Sci 42 (4): 156-162.

Seguel A, Cumming JR, Klugh-Stewart, Cornejo P, Borie F. 2013. The role of arbuscular mycorrhizas in decreasing aluminium phytotoxicity in acidic soils: a review. Mycorrhiza 23: 167-183.

Setiadi Y, Setiawan A. 2011. Study of arbuscular mycorrhizal fungi status at rehabilitation post-nickel mining area (case study at PT INCO Tbk. Sorowako, South Sulawesi). Jurnal Silvikultur Tropika 2 (2): 88-95. [Indonesian]

Sheoran V, Sheoran AS, Poonia P. 2010. Soil reclamation of abandoned mine land by revegetation: a review. Intl J Soil Sediment Water 3 (2): $1-20$.

Shi-chu L, Yong J, Ma-bo L, Wen-xu Z, Nan X, Hui-hui Z. 2019. Improving plant growth and alleviating photosynthetic inhibition from salt stress using AMF in alfalfa seedlings. J Plant Interact 14 (1): 482-491.

Sikes BA, Cottenie K, Klironomos JN. 2009. Plant and fungal identity determines pathogen protection of plant roots by arbuscular mycorrhizas. J Ecol 97: 1274-1280.

Silvana VM, Carlos FJ, Lucía AC, Natalia A, Marta C. 2018. Colonization dynamics of arbuscular mycorrhizal fungi (AMF) in Ilex paraguariensis crops: Seasonality and influence of management practices. J King Saud Univ Sci 32 (1): 183-188. DOI: 10.1016/j.jksus.2018.03.017.

Singh AN, Raghubanahi AS, Singh JS. 2004. Impact of native tree plantations on mine spoil in a dry tropical environment. For Ecol Manag 187: 49-60.

Singh AK, Jamaluddin J. 2011. Status and diversity of arbuscular mycorrhizal fungi and its role in natural regeneration on limestone mined spoils. Biodiversitas 12 (2): 107-111.

Smith FA, Jakobsen I, Smith SE. 2000. Spatial differences in acquisition of soil phosphate between two arbuscular mycorrhizal fungi in symbiosis with Medicago truncatula. New Phytol 147: 357-366.

Smith SE, Read DJ. 2008. Mycorrhizal Symbiosis. Thrid Edition. Academic Press is an imprint of Elsevier, United Kingdom.

Soka GE, Ritchie ME, Mayemba EP. 2015. Influence of current land use and edaphic factors on arbuscular mychorrizal (AM) hyphal abundance and soil organic matter in and near Serengeti National Park. J Ecol Nat Environ 7 (5): 158-169.

Sousa CS, Menezes RSC, Sampaio EVSB, Lima FS, Maia LC, Oehl F. 2014. Arbuscular mycorrhizal fungi in successional stages of Caatinga in the semi-arid region of Brazil. Cienc Florestal 24 (1): 137-148.

Suharno, RS Kasiamdari, ES Soetarto, RP Sancayaningsih. 2016. Presence of arbuscular mycorrhizal fungi on fern from tailin deposition area of go mine in Timika, Indonesia. Int $\mathbf{J}$ Environ Bioremed Biodegrad 4 (1): 1-7.

Suharno, Soetarto ES, Sancayaningsih RP, Kasiamdari RS. 2017. Association of arbuscular mycorrhizal fungi (AMF) with Brachiaria precumbens (Poaceae) in tailing and its potential to increase the growth of maize (Zea mays). Biodiversitas 18: 433-441.

Thirkell TJ, Cameron DD, Hodge A. 2016. Resolving the 'nitrogen paradox' of arbuscular mycorrhizas: Fertilization with organic matter brings considerable benefits for plant nutrition and growth. Plant Cell Environ 39: 1683-1690.

Tian H, Drijber RA, Niu XS, Zhang JL, Li XL. 2011. Spatio-temporal dynamics of an indegenous arbuscular mycorrhizal fungal community in an intensively managed maize agroecosystem in North China. Appl Soil Ecol 47 (3): 141-152.

Tuheteru FD, Husna, Albasri, Arif A, Wulan SA, Kramadibrata K. 2019. Arbuscular mycorrhizal fungi associated with adaptive plants in gold mine tailing. Biodiversitas 20 (11): 3398-3404.

Ulfa M, Kurniawan A, Sumardi, Sitepu I. 2011. Population of indigenous arbuscular mycorrhizal fungi (AMF) in post coal-mining land. Jurnal Penelitian Hutan dan Konservasi Alam 8 (3): 301-309. [Indonesian]

Velázquez MS, Fabisik JC, Abarca CL. 2018. Colonization dynamics of arbuscular mycorrhizal fungi (AMF) in Ilex paraguariensis crops: 
Seasonality and influence of management practices. J King Saud Univ Sci 32 (1): 183-188. DOI: 10.1016/j.jksus.2018.03.017.

Veresoglou SD, Rillig MC. 2012. Suppression of fungal and nematode plant pathogens through arbuscular mycorrhizal fungi. Biol Lett 8 (2): 214-217.

Wang F. 2017. Occurrence of arbuscular mycorrhizal fungi in miningimpacted sites and their contribution to ecological restoration: Mechanisms and applications. Cit Rev Environ Sci Technol 470: 157.

Wick AF, Ingram LJ, Stahl PD. 2009. Aggregate and organic matter dynamics in reclaimed soils as indicated by stable carbon isotopes. Soil Biol Biochem 41 (2): 201-209.

Wu QS, Srivastava AK, Cao MQ, Wang J. 2015. Mycorrhizal function on soil aggregate stability in root zone and root-free hyphae zone of trifoliate orange. Arch Agron Soil Sci 61 (6): 813-825.

Wulandari D, Saridi, Cheng W, Tawaraya K. 2016. Arbuscular mycorrhizal fungal inoculation improves Albizia saman and Paraserianthes falcataria growth in post-opencast coal mine field in East Kalimantan, Indonesia. For Ecol Manag 376: 67-73.
Yang H, Dai Y, Wang X, Zhang Q, Zhu L, Bian X. 2014. Meta-analysis of interactions between arbuscular mycorrhizal fungi and biotic stressors of plants. Sci World J. DOI:10.1155/2014/746506.

Zhang F, Du P, Song C-X, Wu Q-S. 2015. Alleviation of magnesium deficiency by mycorrhiza in trifoliate orange: changes in physiological activity. Emir J Food Agric 27 (10): 763-769.

Zhang H, Wei S, Hu W, Xiao L, Tang M. 2017. Arbuscular mycorrhizal fungus rhizophagus irregularis increased potassium content and expression of genes encoding potassium channels in Lycium barbarum. Front Plant Sci 8: 440. DOI: 10.3389/fpls.2017.00440.

Zhao H, Li X, Zhang Z, Zhao Y, Yang J, Zhu Y. 2017. Species diversity and drivers of arbuscular mycorrhizal fungal communities in a semiarid mountain in China. PeerJ 5: e4155. DOI: 10.7717/peerj.4155.

Zangaro W, Alves RA, Lescano LEAM, Ansanelo AP, Nogueira MA. 2012. Investment in fine roots and arbuscular mycorrhizal fungi decrease during succession in three Brazilian ecosystems. Biotropica 44: 141-150.

Zipper CE, Burger JA, McGrath JM, Rodrigue JA, Holtzman GI. 2011. Forest restoration potential of coal-mined lands in the Eastern United States. J. Environ Qual 40: 1567-1577. 